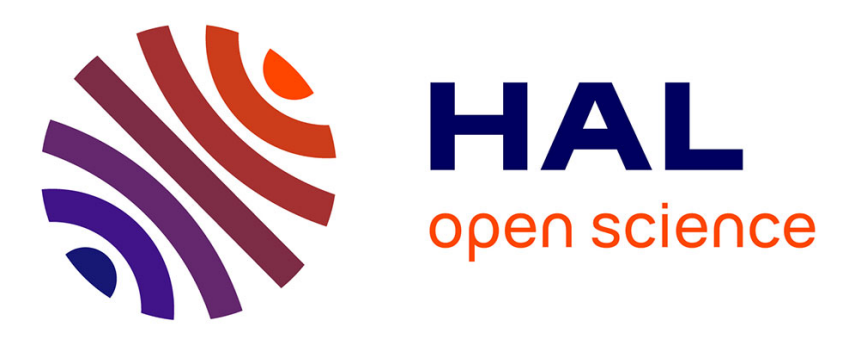

\title{
The Directions of Psychiatric Research by Emil Kraepelin
}

Eric J. Engstrom, Matthias M. Weber

\section{To cite this version:}

Eric J. Engstrom, Matthias M. Weber. The Directions of Psychiatric Research by Emil Kraepelin. History of Psychiatry, 2005, 16 (3), pp.345-349. 10.1177/0957154X05056763 . hal-00570829

\section{HAL Id: hal-00570829 \\ https://hal.science/hal-00570829}

Submitted on 1 Mar 2011

HAL is a multi-disciplinary open access archive for the deposit and dissemination of scientific research documents, whether they are published or not. The documents may come from teaching and research institutions in France or abroad, or from public or private research centers.
L'archive ouverte pluridisciplinaire HAL, est destinée au dépôt et à la diffusion de documents scientifiques de niveau recherche, publiés ou non, émanant des établissements d'enseignement et de recherche français ou étrangers, des laboratoires publics ou privés. 


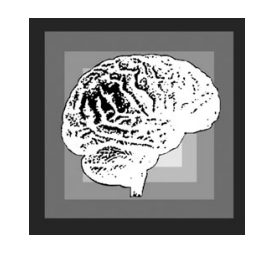

Classic Text No. 63

\title{
The Directions of Psychiatric Research by Emil Kraepelin
}

\author{
Introduction and translation by \\ ERIC J. ENGSTROM* \\ Charité - Universitätsmedizin Berlin
}

MATTHIAS M. WEBER

Max-Planck-Institut für Psychiatrie, Munich

\begin{abstract}
This classic text reproduces Emil Kraepelin's inaugural lecture at the University of Dorpat in 1887. It represents one of the most succinct contemporary surveys of German psychiatric discourse in the 1880s. It also outlines Kraepelin's own research priorities in the early years of his career, providing important historical background to the motives that drove him to place such great emphasis on (and hope in) experimental psychology. Contrary to our contemporary image of Kraepelin as a grand clinical nosologist, this text shows that he was much more of a diagnostician and experimental psychologist than historians have generally assumed. The document also reflects a wider 'psychological turn' in German psychiatry, away from patho-anatomic study - a turn that has often been overlooked in the historiographic literature.
\end{abstract}

Keywords: Emil Kraepelin; experimental psychology; psychiatric diagnosis; quantitative psychopathology; Wilhelm Wundt

\section{Introduction}

The enormous influence of Emil Kraepelin within the discipline of psychiatry is commonly attributed to the clinical methodology that he introduced as a

* Address for correspondence: Institute for the History of Medicine, ZHGB (Humboldt University - FU Berlin), Charité - Universitätsmedizin Berlin, Ziegelstrasse 5-9, 10117 Berlin, Germany. Email: eric.engstrom@charite.de 
means of isolating specific categories of madness. According to advocates and detractors alike, his unique powers of observation and empirical research techniques were decisive factors in the dichotomous delineation of the endogenous psychoses. So it is hardly surprising - and certainly not without some justification - that we have come to view Kraepelin as a clinical nosologist.

But Kraepelin was not the man he has become in our eyes. In fact, in 1887 he was not a clinical nosologist at all. On the contrary. A far more apt description of him at this point in his career would be that of an experimental psychologist and psychiatric diagnostician. Indeed, his greatest concern throughout the $1880 \mathrm{~s}$ - and later - seems to have been diagnostic accuracy, not taxonomic validity.

An obvious manifestation of this concern was his abiding passion for experimental psychology. As a young psychiatrist working in the laboratory of Wilhelm Wundt (1832-1920) in the early 1880s, he conducted numerous psychophysical experiments designed to test mental capacity as well as the effects of pharmacological and other stimulants. He later built laboratories in Dorpat, Heidelberg and Munich and founded a journal (Psychologische Arbeiten) dedicated to research in experimental psychology. For well over forty years, up to the very end of his career, Kraepelin conducted research in experimental psychology and remained convinced of its importance in the development of psychiatric science.

Kraepelin's inflated legacy as a nosologist has done much to obscure his efforts to establish psychological methods as part of the psychiatrist's diagnostic repertoire. In fact, traditional interpretations of Kraepelin's work have generally ignored the psychological experiment, coming to view it as little more than an awkward appendage to his larger cuvre (see Birnbaum, 1928: 42; Gaupp, 1939: 46; Gruhle, 1929: 68). Of course, from the perspective of clinical medicine, Kraepelin's hopes of integrating experimental findings into his broader nosological scheme were never fulfilled. His enormously influential textbook was all but silent on the relevance of the psychological experiment to psychiatric practice. Hence, it is not surprising that it has been ignored and largely purged from historical memory, while at the same time his pragmatic and useful taxonomy was readily canonized by clinical psychiatry. Yet, as Paul Hoff (1994: 172) has pointed out, Kraepelin considered himself much more of a diagnostician than a nosologist. As paradoxical as it may sound in a Neo-Kraepelinian age, Kraepelin would have agreed with those who later sought to 'denosologize' his legacy.

An important document in this respect is Kraepelin's inaugural lecture at Dorpat in 1887. Its significance lies in helping us to reconstruct Kraepelin's early research priorities and the historical context in which he set them. Specifically, and perhaps most strikingly, the lecture illustrates how he was trying both to distance himself from pathological anatomy and to rehabilitate a psychological dimension to psychiatric research. It will perhaps come as a 
surprise to many readers to discover that Kraepelin flatly contradicted Wilhelm Griesinger's maxim that mental illness was a brain disease. ${ }^{1}$ Although Kraepelin paid glowing tribute to Griesinger and his somatic legacy, he also believed that Griesinger's students - and neuropathologists in general - had made two fundamental errors. First, they had been too eager to draw clinical conclusions from laboratory research. The result had been highly speculative effusions - especially on the part of Theodor Meynert about the causal linkage between psyche and soma. Second, Kraepelin criticized those brain-researchers who had blazed a trail into neuropathology, but who had never found their way back to psychiatry. In his view, the failings of romantic medicine had driven many researchers to opposite extremes and led them to adopt positions of 'naive materialism'. As a result, large swaths of their patho-anatomic research had become irrelevant or only peripherally significant to psychiatry proper.

It is in the context of these failings of cerebral pathology that Kraepelin situated his own research agenda. His scepticism of the approaches of Meynert, Westphal, Wernicke and others reflects an important shift away from the mechanistic and materialist assumptions that had pushed psychiatry towards pathological anatomy from mid-century onwards. While Kraepelin never doubted the somatic origins of madness, he did insist that pathological anatomy and physiology were themselves incapable of grasping the complexity of the psyche. Reflecting the psychophysical parallelism of his mentor Wilhelm Wundt, Kraepelin therefore insisted that psychological experimentation was needed in order to explain mental processes. He argued that because Wundt had transformed psychology into a natural science, psychiatrists could now embrace it unreservedly and thus move the study of mental processes to the fore of psychiatric research. ${ }^{2}$

In assessing the significance of Kraepelin's experimental psychology, some recent commentators, far from discounting its importance, have tended to stress its formative influence on his nosology. Unlike those who admire Kraepelin as a great clinical nosologist, their aim has been to downplay the clinical side of Kraepelin's nosology and emphasize instead its origins in premises drawn from laboratory practice (see Hildebrandt, 1993; Roelcke, 1999). ${ }^{3}$ But here again, the interpretive framework has been retrospectively nosological. That is to say, the significance of Kraepelin's experimental research has been assessed against the monumental backdrop of what Kraepelin's nosology later became. By interpreting experimental psychology's significance - or lack thereof - simply in relation to Kraepelin's nosology, these interpretations have to some degree fallen victim to hindsight, i.e., to the inflated legacy of that nosology.

For what these interpretations tend to miss, and what this classic text demonstrates, is that Kraepelin was rather sceptical about the prospects of clinical research and nosology. Although demarcating categories of psychiatric illness may have been an admirable aim, Kraepelin found most of these 
endeavours to be rife with 'speculation'. He lamented the 'labyrinth of clinical signs' and the sharp 'divergence of efforts at clinical classification' that plagued clinical research. And so he argued that, for the immediate future, research efforts would best be directed not towards the construction of disease categories or nosologies, but rather towards the supposedly more modest goals of delineating clinical symptoms and breaking complicated psychological processes down into their component parts.

Put succinctly, Kraepelin's research agenda in the late 1880s had, first and foremost, diagnostic aspirations. He hoped that his experimental methodology would enhance diagnostic accuracy and reliability and thereby - among its many other advantages ${ }^{4}-$ bring greater scientific rigour to psychiatric practice. Just as other branches of medicine deployed arrays of physical and chemical tests to establish the status praesens of their patients, so Kraepelin hoped to deploy psychological tests and procedures that would ensure - as he would later put it - a 'rapid psychological mapping of the individual' (Kraepelin, 1895: 69). Of course, Kraepelin never succeeded in achieving this goal. But situating diagnostic concerns at the forefront of his early research agenda suggests that deficiencies of psychiatric practice were paramount in his thinking at this time.

Finally, if 'disease course' became the chief defining characteristic of Kraepelin's so-called Verlaufspsychiatrie, then it is striking how little attention he paid to it in his inaugural lecture as compared with experimental psychology. ${ }^{5}$ Indeed, the discrepancy suggests that Kraepelin clearly recognized the limits of the very laboratory methods he espoused - methods that could capture only a snapshot of symptoms at one given moment in patients' lives and that depended on those patients' cooperation for success. These and other limitations, far from constricting his clinical perspective, probably prompted him to widen his later research agenda in Heidelberg to include intensive anamnestic and catamnestic assessments (see Berrios and Hauser, 1988; Engstrom, 2005; Weber and Engstrom, 1997). In other words, Kraepelin's early experimental research is likely to have been a catalyst for his later clinical research in Heidelberg in the sense that it evoked recognition of the importance of disease course and prompted him to expand the breadth of available information about patients beyond what laboratory tests could provide. Accordingly, a more apt interpretation of the origins of Kraepelinian psychiatry would have experimental psychology neither dismissed entirely nor posited as the wellspring of his clinical research, but instead viewed as a necessary though insufficient precondition of accurate diagnostic practice.

\section{Notes}

1. On Griesinger, see: Engstrom, 2003a: 51-87; Sammet, 2000.

2. Although Kraepelin published several articles in the 1880 s and early 1890 s, a full programmatic explication of his views on psychological experimentation did not appear until 1895 in the first volume of his own journal Psychologische Arbeiten (Kraepelin, 1895). 
3. Elsewhere we have distinguished between 'associative' and 'dissociative' interpretations of the psychological experiment's relevance for Kraepelin's nosology (see Burgmair, Engstrom and Weber, 2003: 49-53).

4. On other personal, professional, and institutional advantages of the psychological experiment, see Engstrom, $2003 b$.

5. The language barrier that Kraepelin faced vis-à-vis his Estonian patients was probably another factor in his strong emphasis on experimental psychology in the late $1880 \mathrm{~s}$.

\section{References}

Berrios, G. E. and Hauser, R. (1988) The early development of Kraepelin's ideas on classification - a conceptual history. Psychological Medicine, 18, 813-21.

Birnbaum, K. (1928) Geschichte der Psychiatrischen Wissenschaft. In O. Bumke (ed.), Handbuch der Geisteskrankheiten, Vol. 1 (Berlin: Springer).

Burgmair, W., Engstrom, E. J. and Weber, M. M. (eds) (2003) Kraepelin in Dorpat (Munich: Belleville).

Engstrom, E. J. (2003a) Clinical Psychiatry in Imperial Germany: A History of Psychiatric Practice (Ithaca, NY: Cornell University Press).

Engstrom, E. J. (2003b) La messende Individualpsychologie: sur le rôle de l'expérimentation psychologique dans la psychiatrie d'Emil Kraepelin. Psychiatrie - Sciences Humaines Neurosciences, 1 (1), 53-61 and 1 (2), 40-6.

Engstrom, E. J. (2005) Die Ökonomie klinischer Inskription: Zu diagnostischen und nosologischen Schreibpraktiken in der Psychiatrie. In Cornelius Borck \& Armin Schäfer (eds), Psychographien (Zurich: Diaphenes), 77-98 (in press).

Gaupp, R. (1939) Die Lehren Kraepelins in ihrer Bedeutung für die heutige Psychiatrie. Zeitschrift für die gesamte Neurologie und Psychiatrie, 165, 47-75.

Gruhle, H. W. (1929) Kraepelins Bedeutung für die Psychologie. Archiv für Psychiatrie und Nervenkrankheiten, 87, 43-9.

Hildebrandt, H. (1993) Der psychologische Versuch in der Psychiatrie: Was wurde aus Kraepelins (1895) Programm? Psychologie und Geschichte, 5, 5-30.

Hoff, P. (1994) Emil Kraepelin und die Psychiatrie als klinische Wissenschaft. Ein Beitrag zum Selbstverständnis psychiatrischer Forschung (Berlin: Springer).

Kraepelin, E. (1895) Der psychologische Versuch in der Psychiatrie. Psychologische Arbeiten, 1, $1-91$.

Roelcke, V. (1999) Laborwissenschaft und Psychiatrie. Prämissen und Implikationen bei Emil Kraepelins Neuformulierung der psychiatrischen Krankheitslehre. In Thomas Schlich and Christoph Gradmann (eds), Strategien der Kausalität: Konzepte der Krankheitsverursachung im 19. und 20. Fahrhundert (Pfaffenweiler: Centaurus), 93-116.

Sammet, K. (2000) Ueber Irrenanstalten und deren Weiterentwicklung in Deutschland: Wilhelm Griesinger im Streit mit der konservativen Anstaltspsychiatrie 1865-1868 (Hamburg: Lit).

Weber, M. and Engstrom, E. J. (1997) Kraepelin's 'diagnostic cards': the confluence of clinical research and preconceived categories. History of Psychiatry, 8, 375-385. 